\title{
Changes in TRP Channels Expression in Painful Conditions
}

\author{
Mahendra Bishnoi ${ }^{1}$ and Louis S. Premkumar*,2 \\ ${ }^{I}$ Department of Nutritional Sciences and Technology Institute (NABI), SAS Nagar, Punjab-60071, India; ${ }^{2}$ Department of \\ Pharmacology, Southern Illinois University School of Medicine, Springfield, IL-62702, USA
}

\begin{abstract}
Over the last fifteen years after the successful cloning of the first nociceptive Transient Receptor Potential (TRP) channel, TRP Vanilloid 1, other members of the TRP channel family have been cloned, characterized and implicated in different modalities of pain. Tremendous progress has been made with regard to the specific role of these TRP channels in nociception using electrophysiological and molecular methods, along with behavioral models combined with gene disruption techniques. This review summarizes the evidence supporting the role of TRP channels (TRP Vanilloid 1, TRP Vanilloid 2, TRP Vanilloid 3, TRP Vanilloid 4, TRP Ankyrin 1, TRP Melastatin 2, TRP Melastatin 3, TRP Melastatin 8, TRP Mucolipin 3 and TRP Canonical 1,6) involved in nociception. The review also highlights the current status and future avenues for developing TRP channel modulators as analgesic agents.
\end{abstract}

Keyword: Analgesia, Inflammation, nociception, pain, TRP channels.

\section{INTRODUCTION}

"Pain is an unpleasant sensory and emotional experience associated with actual or potential tissue damage, or described in terms of such damage". Pain is a major symptom in many medical conditions and is the most common reason for consultation with physicians in the United States. It can significantly interfere with day to day activities and affect the quality of life.

Based on the duration, pain can be classified as acute or chronic. Acute pain has a short duration, identifiable pathology, and the pain is alleviated with over the counter analgesics. Whereas, chronic pain has an unpredictable prognosis, unclear pathology, and requires polypharmacy approach; some of which are prescription medications. Pathophysiological classification of pain include: acute/nociceptive, inflammatory and chronic/neuropathic. Acute/nociceptive pain is detected and transmitted by nociceptors and is resolved within seconds or minutes; inflammatory pain is associated with inflammation and persists as long as the inflammation lasts; chronic/neuropathic pain may or may not have a peripheral component and persists for months to years, even after the initial injury has healed.

Nociceptors are of two types: 1) small diameter cell bodies with unmyelinated $\mathrm{C}$ fibers; 2) medium diameter cell bodies with thinly myelinated A- $\delta$ fibers. The management of chronic pain is a major unmet medical need in our society because of inadequate responsiveness to currently available pain therapies such as nonsteroidal anti-inflammatory drugs

*Address correspondance to this autor at the Professor of Pharmacology, Southern Illinois University School of Medicine, Springfield, IL, 62702, USA; Tel: 217545 2179; Fax: 217545 0145;

E-mail: lpremkumar@siumed.edu
(NSAIDs), opioids, anti-epileptics and tricyclic antidepressants. Chronic pain is associated with certain diseases and the occurrence of which is steadily increasing (e.g., arthritis, diabetes, viral infections, cancer and AIDS). There has been growing interest in pursuing novel pharmacological approaches targeting newly identified receptors that include the family of ion channels called Transient Receptor Potential (TRP) channels. Here we will describe the expression and function of nociceptive TRP channels that may be targets for next generation analgesics.

\section{TRANSIENT RECEPTOR POTENTIAL CHANNELS}

To date, more than 30 mammalian Transient Receptor Potential (TRP) channels have been cloned and characterized. They are grouped into six subfamilies on the basis of their amino acid sequence homology: TRPC ("canonical"), TRPM ("melastatin"), TRPV ("vanilloid"), TRPA ("ankyrin"), TRPML ("mucolipin"), and TRPP (or PKD) ("polycystin"). Most of TRP channels are nonselective cation channels expressed at the plasma membrane with a high permeability to $\mathrm{Ca}^{2+}$. They are responsible for several physiological and pathophysiological functions, ranging from sensory functions (such as vision, nociception, taste transduction, temperature sensation and pheromone signaling) to homeostatic functions (such as $\mathrm{Ca}^{2+}$ and $\mathrm{Mg}^{2+}$ flux and osmoregulation). TRP channels are associated with several pathophysiological conditions involving the disciplines of neurology, dermatology, pulmonology, cardiology, urology, oncology and heritable diseases. The role of TRP channels in pain is reasonably well understood. TRPV1, TRPV3 and TRPA1 channel antagonists have already advanced to clinical trials, whereas other TRP channel antagonists are in preclinical development. Ever increasing number of animal models and gene-disrupted animals has unraveled the role of other TRP channels 
(TRPV2, TRPV4, TRPM2, TRPM3, TRPM8, TRPML3 and TRPC) in painful conditions. In the following sections we will summarize the expression and function of different TRP channels involved in nociception.

\section{TRANSIENT RECEPTOR POTENTIAL VANILLOID 1 (TRPV1)}

TRPV1, a nonselective cation channel that has high permeability to $\mathrm{Ca}^{2+}$ ions was cloned and characterized by David Julius and colleagues in 1997 [1]. TRPV1 consists of a long intracellular N-terminus with three ankyrin-repeat domains and the intracellular $\mathrm{C}$-terminus that consists of a TRP domain. Given the co-expression of other TRP channels in the same nociceptor, the possibility of forming heteromultimers with TRPV2 or TRPV3 has been suggested [2-4].

TRPV1, a polymodal receptor is expressed at the peripheral terminals of a subset of neurons in dorsal root ganglia (DRG), trigeminal ganglia (TG), nodose ganglia (NG) and jugular ganglia ( $\mathrm{JG}$, superior ganglion of glossopharyngeal nerve) $[5,6]$. They are also present at the central terminals where they form synapses with the second order neuron in the substantia gelatinosa (SG), cadual spinal trigeminal nucleus (CSTN) and nucleus tractus solitarius (NTS) [7-15]. They are expressed in the areas that are involved in ascending and descending pain pathway such as hypothalamus, thalamus, ventral medulla and periaqueductal gray [16]. TRPV1 has been shown to be distributed in other nonsensory regions of the brain such as raphe nucleus, locus coeruleus, hippocampus, ventral tegmental area, cerebellum, substania nigra and somatosensory cortex [17-22]. A Number of single-nucleotide polymorphisms have been described in the TRPV1 gene; the "G" allele (rs222747) has been found to increase channel activity and in human enhance cortical excitability as compared to "non-G" allele (rs222749) [23]. Recently, genetic reporter mice approach has indicated very sparse distribution of TRPV1 in the CNS $[24,25]$.

TRPV1 is predominantly expressed in C-and A $\mathrm{A}$ type nociceptors and has been shown to be involved in the transmission of inflammatory thermal hypersensitivity. In consensus with this idea, TRPV1 knock-out mice are able to sense pain associated with acute temperature, but inflammation-induced thermal hypersensitivity is significantly reduced $[1,26,27]$. TRPV1 expressed at the peripheral terminals of nociceptors and is activated by heat $\left(>42^{\circ} \mathrm{C}\right)$ and responsible for transmitting acute noxious thermal sensation and inflammatory thermal hypersensitivity.

Capsaicin (pungent ingredient of hot chili peppers) is a potent exogenous ligand for TRPV1 that has been extensively used in the field to characterize TRPV1 properties; this included functional cloning of TRPV1 where cells that responded to capsaicin-induced $\mathrm{Ca}^{2+}$ influx were isolated and propagated [1]. Resiniferatoxin (RTX), (obtained from the cactus, Euphorbia resinifera) is a high affinity agonist, which has been very useful to delineate the expression and functions of TRPV1 $[1,28,29]$. TRPV1 is also activated by spider and jellyfish toxin $[30,31]$.
TRPV1 is activated by several endogenous agonists that include protons [1], anandamide [32], Arachidonic Acid (AA) metabolites, N-arachidonyl dopamine (NADA), oleoylethanolamide (OEA), N-oleyldopaine (NODA), polyamines [33, 34] and adenosine [35]. TRPV1 is robustly potentiated by pro-inflammatory agents and trophic factors. The activation temperature threshold is reduced below the body temperature when the receptor is in the phosphorylated state $[10,36]$. TRPV1 is sensitized by activin [37], adenosine triphosphate (ATP) [38-40], bradykinin (BK) [36, 41, 42], glutamate [43], histamine [44], proteinase-activated receptor2 [45], serotonin [46], trypsin [45, 47], nerve growth factor (NGF) [48-50], glial cell derived neurotrophic factor [50], and insulin/insulin like growth factor 1 (IGF-1) [51, 52].

Both TRPV1 agonists and antagonists are capable of inducing pain relief. Antagonism of TRPV1 receptor prevents the generation of receptor potential in response to temperature and endogenous ligands. However, while using potent endogenous agonists the generation of receptor potential and subsequent action potential is prevented by either desensitization of the receptor or by depolarization block of the nerve terminal [11,53]. Desensitization of TRPV1 receptor is dependent on the concentration of the agonist and the $\mathrm{Ca}^{2+}$ influx through the receptor $[11,53]$. Persistent activation of TRPV1 by low concentrations of agonists can cause nerve terminal depolarization by maintaining the sodium channels in an inactivated state, thereby preventing nociceptive transmission in the shortterm and enhancing $\mathrm{Ca}^{2+}$ influx into the nerve terminal causing nerve terminal ablation in the long-term [11]. Therefore, both peripheral and central nerve terminals at the spinal cord can be targeted to induce pain relief by TRPV1 agonists [11]. Administration of capsaicin and RTX increases the frequency of sEPSCs without altering the amplitude, suggesting a presynaptic locus of action. Capsaicin induces a desensitizing response, whereas RTX induces a sustained response $[10,11]$. Interestingly, while recording evoked synaptic currents, synaptic failures were observed [11]. Intrathecal administration of RTX reduces inflammatory thermal hypersensitivity, without altering acute thermal pain sensitivity $[11,54]$. Furthermore, it has been found in immunostaining studies that following intrathecal administration of RTX TRPV1 staining in the central sensory nerve terminals was completely abolished, whereas the staining of the cell bodies in the DRG and the peripheral terminals in the skin remained intact $[11,54]$. Based on these findings, it is proposed that sensory efferent functions that are dependent on CGRP and substance P (SP) release from the peripheral nerve terminals would not be affected following intrathecal administration of RTX [11, 54]. To test the effectiveness of intrathecal administration of RTX in treating cancer pain, a clinical trial has been initiated (Study NCT008041; Sponsor: National Institute of Dental and Craniofacial Research (NIDCR).

Several newer TRPV1 antagonists have been synthesized and characterized. SB-366791 is a competitive inhibitor of TRPV1 that blocks all modes of TRPV1 activation (capsaicin, acid and heat) $[55,56]$. Spontaneous and miniature excitatory synaptic currents recorded from the substantia gelatinosa neurons following administration of complete Freund's adjuvant (CFA)-injected animals were decreased following administration of SB-366791 [56]. SB- 
782443 showed excellent potency in human, guinea pig, and rat TRPV1 and exhibited a favorable pharmacokinetics profile while testing in inflammatory pain models $[57,58]$. Further research has led to the development of two other TRPV1 antagonists, SB-705498 and SB-452533.

A-425619, a competitive antagonist inhibits $\mathrm{Ca}^{2+}$ influx and membrane currents elicited by capsaicin, NADA, anandamide or protons. A-425619 blocks TRPV1-mediated current at lower concentrations, when the receptor is in the phosphorylated state [59]. It reduces pain associated with inflammation and tissue injury in rats [60]. A-784168 is able to penetrate the CNS significantly, but not A-795614. Both of these compounds exhibit equal efficacy when given intrathecally, however when administered orally, A-784168 shows higher efficacy [61].

Amgen has developed several potent TRPV1 antagonists (AMG517, AMG0347, AMG8163, and AMG9810) and some of them had entered phase I clinical trials [61]. Neurogen/Merck has launched NDG-8243/MK-2295 in Phase II clinical trials. Other TRPV1 antagonists that have been developed include GRC-6211 (Glenmark/Eli Lilly), ABT-102 (Abbott), JNJ-17203212 (Johnson and Johnson), SAR115740 (Sanofi Aventis), and JYL1421 (Pacific corp.) [62-64]. Recently, endogenous substances known as resolvins have been found to be potent inhibitors of TRPV1 and TRPA1 and are able alleviate inflammatory pain when administered intrathecally $[65,66]$.

TRPV1 agonists/antagonists have been demonstrated to be beneficial in pain induced by arthritis, bone cancer, diabetic peripheral neuropathy, herpes zoster, inflammatory bowel disease and migraine [67-72]. Several TRPV1 antagonists are in clinical trials for these conditions [62-64, 73, 74]. A major side effect encountered in clinical trials while using TRPV1 antagonists was hyperthermia [75-77]. This unexpected side effect has led major pharmaceutical companies to halt their efforts of pursuing TRPV1 antagonists as analgesics and has prompted the search for novel targets.

\section{TRANSIENT RECEPTOR POTENTIAL VANILLOID 2 (TRPV2)}

TRPV2 was cloned soon after the cloning of TRPV1 and has a 50\% sequence homology to TRPV1 and transmits noxious heat sensation [78, 79]. It is activated by temperature $\left(>52{ }^{\circ} \mathrm{C}\right)$, mechanical stretch, osmotic stimuli, chemicals such as cannabinoids [80], probenecid [81] and 2aminoethoxydiphenyl borate (2-APB) [82, 83].

TRPV2 is abundantly expressed in nociceptors, the cell bodies of which are located in DRG, TG, and NG. TRPV2 is expressed all through the spinal cord, including laminae III and IV, suggesting a broader role than TRPV1, which is expressed only in laminae I and II [78, 84-87]. TRPV2 is expressed in tyrosine kinase $\mathrm{C}(\operatorname{trkC})$ and neurotrophin 3 (NT3) receptor expressing neurons in the spinal cord suggesting a role in trkC and NT3 receptor-mediated thermal and mechanical hypersensitivity $[88,89]$. The expression of TRPV2 in neurons innervating the larynx, bladder and intestine suggests its role in sensory functions of the internal organs [90-93].
Translocation of channels from the intracellular pools to the plasma membrane is an effective way of enhancing the function of a channel. Stimulation of its receptor by insulin like growth factor I (IGF-I) has been shown to enhance the plasma membrane content of TRPV2 [94]. Other intracellular regulators such as $\mathrm{Ca}^{2+} /$ calmodulin- dependent protein kinase (CAMK) [95], phosphatidylinositol 3-kinase (PI3-K) [96], A-kinase anchor protein (AKAP)/cAMP/protein kinase A (PKA)-mediated phosphorylation [97] have been shown to modulate TRPV2 functions. Although it is not clear as to the extent of TRPV1 expression in non-sensory neurons in the brain, heteromerization of TRPV1 and TRPV2 has been demonstrated in the central neurons $[2,98,99]$.

In primates, some of the $\mathrm{A} \delta$-fiber nociceptors exhibit a much higher threshold $\left(\sim 53^{\circ} \mathrm{C}\right)$ that can be sensitized by repetitive applications of heat as demonstrated in recombinant TRPV2. Heat-sensitive, capsaicin-insensitive DRG neurons with an activation thresholds of $>50^{\circ} \mathrm{C}$ have also been observed in rat and mouse DRG cultures [84, 100]. In order to understand the exact role of TRPV2, electrophysiological and behavioral studies using TRPV2 knock-out mice have been performed, which show normal responses to noxious heat and mechanical stimuli both in the basal state and under inflammatory conditions [100].

Individuals with Norrbottnian congenital insensitivity to pain show loss of TRPV2 nerve fibers in their skin, suggesting their role in nociception [101]. TRPV2 expression in dental pulp may play a role in odontogenic pain $[102,103]$. In a recent study, it has been reported that TRPV2 plays a role in mechanically-evoked neurite outgrowth [104]. The role of TRPV2 in nociception is far from clear.

\section{TRANSIENT RECEPTOR POTENTIAL VANILLOID 3 (TRPV3)}

TRPV3 has a high sequence homology with TRPV1 and is located on the same chromosome [105]. TRPV3 is found to be expressed in DRG, TG and NG neurons, keratinocytes, CNS neurons, nasal mucosa, tongue and testis and may play a role in thermoregulation [106].

The warmth produced by camphor when applied on the skin is due to activation of TRPV3, which has been shown to be a potent activator of TRPV3 in in vitro studies. The channel is also activated by menthol (in mint), carvacrol (in oregano), eugenol (in clove), insensol, 2-APB [107] and moderate heat (between $30-35^{\circ} \mathrm{C}$ ) [108]. A possibility of TRPV1 and TRPV3 subunit stoichiometry in the same channel has been suggested because of their co-expression in the same neuron [108].

The endogenous ligand for TRPV3 has not been identified. During inflammation Arachidonic Acid (AA) is produced and the active metabolites of AA (such as prostaglandins) can modulate TRPV3 channel activity. In TRPV3 over-expressing mice, keratinocytes can release prostaglandins and nerve growth factor (NGF) in response to activation of TRPV3 [109]. In several skin conditions, AA levels are increased [110,111]. Further, AA has been shown to activate and sensitize PKC [112]. A possible role of PIP2 in modulating TRPV3 channel has been suggested by agonists that activate PLC [113]. It is possible that IP3- 
mediated $\mathrm{Ca}^{2+}$ release can have a modulatory role, because both extracellular and intracellular $\mathrm{Ca}^{2+}$ inhibit TRPV3 [114].

Since free nerve endings of sensory neurons that carry nociceptive information are tightly surrounded by keratinocytes, it is possible that substances released from keratinocytes such as ATP and prostaglandins can excite TRP channels at the peripheral sensory nerve terminals. This was confirmed by TRPV3 knock-out animals that lacked ATP release from peripheral terminals [115]. In several painful conditions, TRPV3 expression is enhanced such as following mastectomy, in chronic constriction injury, and in avulsed DRG after a nerve injury [108, 116-118].

From the expression pattern and functional characteristics of TRPV3, it is apparent that TRPV3 can be targeted to induce analgesia. TRPV3 knock-out animals have revealed more clearly its role in nociception $[119,120]$. Glenmark Pharmaceuticals involved in developing TRP channel antagonists has developed GRC 15300 , which is in phase I Clinical trials [121]. Hydra Biosciences has developed TRPV3 antagonists, which show effectiveness in animal models of pain [122, 123]. TRPV3 over-expressing animals exhibit a 'hair-less' phenotype indicating the involvement in functions other than nociception [124, 125]. Since TRPV3 is involved in temperature sensation (30$35^{\circ} \mathrm{C}$ ), its role in regulating body temperature has to be clarified [109]. Unexpected hyperthermia caused by TRPV1 antagonists in human studies warrants detailed pharmacological profiling of TRPV 3 antagonists.

\section{TRANSIENT RECEPTOR POTENTIAL VANILLOID 4 (TRPV4)}

TRPV4, a putative mammalian mechanosensitive channel, is a homologue of the Caenorhabditis elegans osmosensory channel (OSM-9) that is expressed in sensory neurons, hypothalamus, trachea, cochlear hair cells, vascular smooth muscle cells, endothelial cells, kidney and keratinocytes [126-130]. TRPV4 is activated by hypotonicity as a result of cell swelling and by shear stress [129-133]. Other activators of TRPV4 include heat $\left(>27^{\circ} \mathrm{C}\right)$, diacyl glycerol (DAG), PKC activating (phorbol 12-myristate 13acetate, PMA) and non-activating (4 $\alpha$-phorbol 12,13didecanoate, 4 $\alpha$-PDD) phorbol esters, and 5',6'epoxyeicosatrienoic acid (5',6'-EET) derived from anandamide and AA [127, 134, 135]. It appears that TRPV4 is involved in sensing sustained mechanical sensation that occurs during vasodilation and cell swelling. It was proposed that second messengers produced during cell swelling can activate the channel $[129,136]$. A direct mechanosensitivity of TRPV4 has been demonstrated recently by its activation by hypotonic solution in a system, independent of polyunsaturated fatty acids [137] and by direct mechanical force in excised membrane patches [138,139].

TRPV4 is expressed in primary afferent nociceptors and transduces subtle changes in osmolarity, which occurs during inflammation and extravasation. Following injection of the simplified "inflammatory soup" (prostaglandin E2 and serotonin), the percentage of $\mathrm{C}$-fibers responding to a hypotonic stimulus and the magnitude of response is significantly weaker in TRPV4 ${ }^{-/-}$mice as compared to $\mathrm{TRPV4}^{+/+}$mice [140]. Osmotransduction was studied using hypotonic or hypertonic solutions, which caused significant nocifensive behavior [140,141]. This behavior is further enhanced by the inflammatory mediator, PGE2. Using antisense-oligodeoxynucleotides, the role of TRPV4 has been implicated in both hypotonic and hypertonic stimulusinduced nociception $[140,141]$. Further, it has been suggested that TRPV4-mediated nocifensive behavior induced by osmotransduction is dependent on Src tyrosine kinase [142].

Using electrophysiological, molecular and behavioral techniques, it has been shown that TRPV4 plays a role in pancreatitis [143]. Immunoreactivity of TRPV4 along with TRPA1 has been detected in pancreatic nerve fibers and in DRG neurons innervating the pancreas. DRG neurons from TRPV4 knock-out mice exhibit significantly attenuated $\mathrm{Ca}^{2+}$ influx in response to TRPV4 agonists. They also exhibit reduced pain and inflammatory response. Therefore, TRPV4 channel antagonists can be effective in the treatment of pain associated with pancreatitis [143]. There are several lines of evidence that TRPV4 is involved in other pain-related conditions. TRPV4 plays a crucial role in painful peripheral neuropathy. Spinal administration of antisense oligodeoxynucleotides to TRPV4 attenuated taxol-induced mechanical hyperalgesia and hypotoniciy-induced hyperalgesia [144]. TRPV4 appears to be in a sensitized state after paclitaxel-induced neuropathy [145]. TRPV4 also plays a critical role in chronic compression of DRG-mediated mechanical allodynia and thermal hyperalgesia. Nitric oxidemediated cGMP or NF- $\kappa$ B pathways could be involved [146148]. Activation of TRPV4 within the meninges initiates afferent nociceptive signaling that may contribute to migraine-type headaches [148]. TNF- $\alpha$ differentially induces TRPV4 expression in synoviocytes [149] which can affect inflammatory pain states. Anti-nociceptive effects of agents such as butamben and dimethylallyl pyrophosphate have been shown to be mediated by TRPV4 $[150,151]$. TRPV4 along with TRPV1 and TRPA1 is a potential integrator of nociception during inflammation. TRPV4 can be an attractive pharmacological target for the development of novel analgesics [152].

\section{TRANSIENT RECEPTOR POTENTIAL ANKYRIN 1 (TRPA1)}

A channel with overlapping sequence homology to TRPA1 was first isolated from human fibroblasts [153]. When TRPA1 was cloned, it was initially named as ANKTM1 [154]. TRPA1 is a non-selective $\mathrm{Ca}^{2+}$ permeable cation channel; it is unique in its structure among TRP channel for having a large number (17) of ankyrin repeat domains, which impart a spring-like action to proteins [155]. TRPA1 is expressed in hair cells, superior cervical ganglion (SCG) neurons, geniculate ganglion, GI tract, heart, brain, urinary bladder and immune cells [156-159]. Its involvement in cold allodynia and mechanical hyperalgesia has been demonstrated using behavioral models [160-164]. TRPA1 is co-expressed with TRPV1 in C and A $\delta$ nociceptors in DRG and TG neurons raising the issue of the functional specificity. Recently, it has been shown that TRPA1 is expressed in rat pancreatic beta cells and involved in insulin release [165]. 
TRPA1 is activated by allicin, diallyldisulfide (in garlic extract), allyl isothiocyanate (AITC, in mustard oil, horseradish and wasabi), cinnamaldehyde (in cinnamon oil), icilin (a synthetic compound that produces a sensation of extreme cold), acrolein (in tear gas and car exhaust) and Nmethyl maleimide (NMM, an oxidizing agent) [166-169]. It is also activated by bradykinin (BK), tetrahydrocannabinoid (THC) and WIN55,212-2 [161, 170-172]. TRPA1 is selectively activated by reactive chemicals produced endogenously, which include $\mathrm{H}_{2} \mathrm{O}_{2}$ /hydroxyl radicals, aldehydes, such as 4-hydroxynonenal (4-HNE), cyclopentenone prostaglandins, such as 15d-PGJ2, methylglyoxal (MG), hypochlorite and hydrogen sulfide $[165,173-175]$. In Drosophila, TRPA1 appears to suggest origin of chemical nociception [176]. Finally, noxious cold temperatures and mechanical force have been proposed to activate TRPA1 [161, 164]. The Drosophila TRP homologue of TRPA1, painless, participates in mechanical nociception, therefore it has been proposed that TRPA1 may respond to mechanical force [176]. However, the role of TRPA1 in sensing cold and mechanical force is still controversial [161, $164,177,178]$.

TRPA1 agonists, cinnamaldehyde, acrolein and mustard oil, when applied topically induce pain in humans [179-181]. Several endogenous activators of TRPA1 (for example, 4hydroxy-nonenal, A- and J-series prostaglandins, BK and $\mathrm{H}_{2} \mathrm{O}_{2}$ that are released following tissue damage and inflammation induce pain behaviors in mice [177-182]. Resolvins have been found to be potent endogenous inhibitors of TRPA1 [65, 66]. TRPA1 antagonists (e.g.HC030031 and CHEM-5861528) reduce acute and chronic inflammatory pain and diabetes-induced neuropathic pain $[183,184]$. In rats, intrathecal administration of TRPA1targeted antisense oligonucleotides or TRPA1 antagonists can also dramatically reduce cold hypersensitivity after nerve injury or inflammation $[159,162]$. A-967079, a TRPA1 antagonist structurally similar to AP-18, reduces cold hypersensitivity after nerve injury without affecting acute responses to environmental cold [185]. Thus, TRPA1 appears to selectively mediate cold hypersensitivity in pathological conditions, where other activators of the channel are also present. Preclinical animal studies and more recently human studies highlight that TRPA1 as a promising new target for the treatment of acute and chronic pain [186]. TRPA1 antagonists by Glenmark Pharmaceuticals, Abbott Laboratories and Hydra Biosciences are in pre-clinical trials [186]. In humans, a gain-of-function TRPA1 mutant has been shown to be involved in familial episodic pain syndrome [187].

\section{TRANSIENT RECEPTOR POTENTIAL MELAS- TATIN 2 (TRPM2)}

TRPM2 has been cloned from human brain, lymphocytes, and monocytes $[188,189]$. The subunits are assembled as homomultimers to form the ion channel pore [190]. The distal C-terminal of TRPM2 channels has strong homology to the NUDT9 proteins and exhibit adenosine 5'diphophoribose (ADPR) pyrophosphatase activity [189]. These channels are permeable to cations including $\mathrm{Ca}^{2+} . \mathrm{Ca}^{2+}$ activates these channels either directly or facilitates the activation via ADPR [189-191]. In addition to ADPR, nicotinamide adenine dinucleotide and their metabolites are capable of activating TRPM2 [192]. TRPM2 can also be activated by molecules produced during oxidative stress such as $\mathrm{H}_{2} \mathrm{O}_{2}$, tumor necrosis factor- $\alpha$ (TNF- $\alpha$ ) and amyloid $\beta$ peptide [182]. The expression of TRPM2 channel has been shown in brain, bone marrow, spleen, heart, liver, lung, pancreatic $\beta$-cells, endothelial cells, immune cells, blood cells and microglia [182].

TRPM2 has been shown to be involved in insulin release, cytokine/chemokine production and apoptotic/necrotic cell death. TRPM2-mediated insulin release is via a $\mathrm{K}_{\mathrm{ATP}}$ channel-independent mechanism [193]. It has been reported that pancreatic $\beta$-cells respond to warm temperatures with increased cytosolic $\mathrm{Ca}^{2+}$ and resultant insulin release through activating TRPM2 channels [193]. Several cellular functions of TRPM2 are related to oxidative stress and generation of reactive oxygen species in numerous cell types [182]. It is involved in the production of chemokine (CXCL8/CXCL2 in monocytes), induction of $\mathrm{Ca}^{2+}$ influx, mediation of cell death (in neurons, monocytes, lymphocytes, insulin secreting cells and cardiomyocytes) [182]. These channels can be nonspecifically inhibited by several compounds such as 8BrcADPR, flufenamic acid (FFA), imidazole anti-fungal agents (clotrimazole and econazole), $\mathrm{N}$-(p-amylcinnamoyl) anthranilic acid (ACA), and 2-APB [182]. There are no specific inhibitors to elucidate the functional role to exploit their therapeutic potential, although TRPM2 knock-out animals have revealed its fundamental functions. TRPM2 is involved in insulin secretion from pancreatic $\beta$-cells, chemokine/cytokine production, cardiovascular diseases (induces endothelial hyper-permeability) and neurodegenerative disorders [182, 193-195]. Ablation of Trpm2 gene reduces chemokine production, neutrophil infiltration, and ulceration in a colitis animal model [196]. Activation of the TRPM2 channel by oxidative stress, TNF- $\alpha$ and $A \beta 42$ and the resultant loss of neuronal cells strongly suggest a role of these channels in the pathophysiology of Alzheimer's disease [197-199]. Altered TRPM2 channel expression and/or function are also reported in several neurological diseases such as stroke, Western Pacific amyotrophic lateral sclerosis and Parkinsonism-dementia [200].

One of the recent studies has suggested the role of TRPM2 channels in inflammatory and neuropathic pain but not in spontaneous pain [201]. TRPM2 expressed in macrophages and microglia aggravates peripheral and spinal pro-nociceptive inflammatory responses and contributes to the pathogenesis of inflammatory and neuropathic pain [201]. Wild-type and TRPM2 knock-out mice showed no difference in their basal thermal and mechanical sensitivities [201]. However, TRPM2 knock-out mice showed significant reduction in formalin-induced nocifensive behavior, carrageenan-induced inflammatory pain and sciatic nerve injury-induced neuropathic pain [201]. Carrageenan-induced inflammation and sciatic nerve injury increased the expression of TRPM2 mRNA in the inflamed paw and around the injured sciatic nerve. Microglial activation, production of CXCL2 and induction of nitric oxide synthase after nerve injury are also suppressed in the spinal cord, cultured macrophages and microglia obtained from TRPM2 knock-out mice [201]. Oxidative stress and depletion of thiol 
groups are implicated in the neuropathology of pain particularly neuropathic pain [201]. TRPM2 is activated by oxidative stress and pro-inflammatory mediators, which is suggestive of its involvement in neuropathic and inflammatory pain conditions [202]. Modulation of TRPM2 channels using N-Acetyl cysteine, 2-APB and flufenamic acid paves the way for understanding the role of TRPM2 in nociception [203-205].

\section{TRANSIENT RECEPTOR POTENTIAL MELAS- TATIN 3 (TRPM3)}

TRPM3 is a voltage-dependent, nonselective cation channel permeable to $\mathrm{Ca}^{2+}$ ions. Using $\mathrm{Ca}^{2+}$ imaging and patch clamp techniques, two TRPM3 (1555-AA and 1325AA containing variants) isoforms have been identified. In the longer variant, intracellular $\mathrm{Ca}^{2+}$ is significantly increased following inclusion of extracellular $\mathrm{Ca}^{2+}$ [206]. Removal of extracellular $\mathrm{Ca}^{2+}$ or application of gadolinium $\left(\mathrm{Gd}^{3+}\right)$ reduces the increases in intracellular $\mathrm{Ca}^{2+}$ confirming the $\mathrm{Ca}^{2+}$ permeability of this channel [207]. From cells expressing shorter TRPM3 variants, whole-cell recordings have revealed $\mathrm{Ca}^{2+}$ and $\mathrm{Mg}^{2+}$ permeability of this isoform as well. Activity of the shorter variant of TRPM3 was suppressed by $\mathrm{Gd}^{3+}$ and $\mathrm{La}^{3+}$, but increased by cell swelling [206]. TRPM3 is expressed in several neuronal and nonneuronal tissues including kidney, brain, endocrine pancreas, vascular smooth muscle, and sensory neurons [207, 208214]. Using Northern blot analyses of mouse brain, at least three transcripts coding for TRPM3 have been detected [206].

TRPM3 has been found to be activated by the endogenous sphingolipid D-erythro-sphingosine (sphingosine) and its precursor, dihydrosphingosine [215]. This activation may be due to the stimulation of the sphingomyelinase/ceramidase pathway, which results in the release and intracellular accumulation of sphingosine [215]. The activation by sphingosine is selective for TRPM3 because other TRP superfamily members did not respond to this lipid compound [206]. Exogenously, pregnenolone sulphate is the most potent activator of TRPM3 channel [212].

Recent reports have implicated the TRPM3 channel as a heat sensor [216]. TRPM3 is functionally expressed in a subset of sensory neurons in DRG and TG. Intraplantar administration of pregnenolone caused nocifensive behavior in wild-type mice but not in TRPM3 knock-out animals $[216,217]$. TRPM3-deficient mice exhibit deficits in their avoidance response to noxious heat, but not to noxious cold or mechanical stimuli. TRPM3-deficient mice also failed to develop inflammatory thermal hypersensitivity [216]. Fenamates and $\mathrm{N}$-phenyl-substituted anthranilic acid derivatives, which are clinically used as non-steroid antiinflammatory drugs, act through TRP channels [204]. One of the potent fenamates, mefenamic acid is a selective and potent TRPM3 blocker, whereas other fenamates also blocked TRPM3, TRPV4, TRPC6 and TRPM2 [204]. All these studies suggest that TRPM3 can be a target for developing analgesics.

\section{TRANSIENT RECEPTOR POTENTIAL MELAS- TATIN 8 (TRPM8)}

TRPM8 was isolated by expression cloning as a menthol receptor from trigeminal neurons by David Julius group, and from sequence homology from genomic database by Ardem Potapoutian group [218, 219]. A channel with a similar sequence homology had already been cloned from prostate cancer cells [220]. TRPM8 is expressed in a subset of C and A $\delta$ nociceptors in DRG and TG. TRPM8 is expressed in peripheral terminals that sense sensory information. TRPM8 is also expressed in the central terminals, the role of which is not clear $[9,221]$.

TRPM8 could be activated by cold temperatures (10$28^{\circ} \mathrm{C}$ ) and 'cooling' compounds such as menthol and icilin. It is also activated by peppermint oil, cornmint oil, eucalyptus oil etc. Lysophospholipids that are produced by the activation of PLA2 has been shown to be an endogenous agonist of TRPM8 [222]. There are no known selective antagonists for TRPM8. Of note, the TRPA1 antagonist HC030031, the TRPV1 antagonist BCTC, and the nonselective agonist of TRPV1, TRPV2 and TRPV3. 2-APB, all block TRPM8 [223-227]. TRPM8 knock-out animals exhibit lack of cold sensitivity, implying an analgesic potential for TRPM8 antagonists. However, the low temperature-induced cold pain was intact in these animals [164, 228, 229]. This is not unexpected since TRPA1, potassium channels and a sodium channel are also involved in cold sensation [230233].

Activation of PKC reciprocally modulates TRPV1 and TRPM8 in that it up-regulates TRPV1 and down-regulates TRPM8 [9]. Differential modulation of PKC and PKA may determine the broader implication of sustained increase in TRPV1-mediated intracellular $\mathrm{Ca}^{2+}$, which could mediate $\mathrm{Ca}^{2+}$ dependent processes such as neurotransmitter/neuropeptide release and transcriptional regulation of proteins. TRPM8 is modulated by PIP2. Depletion of PIP2 by activation of PLC decrease channel activity of TRPM8, but increase the channel activity of TRPV1 [234-236].

The implication of the reciprocal modulation is that thermal hyperalgesia caused by PKC-induced sensitization of TRPV1 by inflammatory mediators could be further aggravated by PKC-mediated down-regulation of TRPM8. Paradoxically, when needed during TRPV1-induced hypersensitivity, TRPM8 is down-regulated. In fact, intraplantar capsaicin-induced nocifensive behavior was alleviated by intraplantar administration of menthol [9]. Therefore, soothing sensation induced by activation of TRPM8 could be useful to alleviate hyperalgesia. The TRPM8 agonist menthol decreases nociceptive responses in inflammatory and neuropathic pain models [237, 238]. On the other hand, TRPM8 antagonism or deletion may also provide pain relief $[186,238]$.

\section{TRANSIENT RECEPTOR POTENTIAL MUCOLIPIN 3 (TRPML3)}

TRPML3 is a cation-selective channel regulated by changes in $\mathrm{pH}$ [239-241]. TRPML3 expression has been reported in hair cells (distributed in intracellular vesicular compartments and plasma membrane) of the 
cochlea/vestibulum and melanocytes [242]. Deletion of TRPML3 causes abnormalities in mitochondrial functioning and lysosomal storage [243]. TRPML3 was discovered in varitint-waddler mice by positional cloning as a result of a mutated channel (gain-of-function mutation (A419P) in the S6 segment. The mutant mice exhibit hearing loss, vestibular defects, pigmentation abnormalities and perinatal lethality $[240,244]$. TRPML3 can be activated by pre-incubation in low sodium medium [241]. Gain-of-function mutants exhibit increased $\mathrm{Ca}^{2+}$ influx and cell death [240]; the loss of melanocytes in the cochlea and the vestibule probably underlies the deafness and the circling behavior of varitintwaddler mice [240, 244].

TRPML3 is significantly down-regulated in the adults but reappears following nerve injury, which has been demonstrated in three different nerve injury models (axotomy, sciatic nerve ligation, spared and partial nerve injury model) [214]. Further, in situ hybridization revealed a significant increase and widespread expression of TRPML3 in both small sized non-peptidergic and peptidergic nociceptors as well as large NF200-positive mechanoreceptors after spinal nerve ligation [214]. A recent report claims the identification of TRPML3 ligand through chemoinformatic analysis that will hopefully serve as useful tools to understand the role of these channels in pain transmission [245].

\section{TRANSIENT RECEPTOR POTENTIAL CANONICAL (TRPC)}

Seven mammalian transient receptor potential canonical (TRPC) proteins (TRPC1-7) have been identified. These channels can be divided into three subgroups by sequence homology: $\mathrm{C} 1 / \mathrm{C} 4 / \mathrm{C} 5, \mathrm{C} 3 / \mathrm{C} 6 / \mathrm{C} 7$, and $\mathrm{C} 2$. All mammalian TRPC proteins seem to be associated with G-protein-coupled receptors and receptor tyrosine kinases [246]. Of these channels, TRPC1 and TRPC6 have been studied for their expression and function in DRG and TG following inflammatory conditions [214].

Stretch activated channels (SACs) are expressed in DRG neurons including TRPC1, TRPC6 and TRPV4 [247]. TRPC1 and TRPC6 along with TRPV4 mediate mechanical hyperalgesia and primary afferent nociceptors sensitization. TRPC1 and TRPC6 channels do not contribute to baseline mechanical nociceptive threshold [248]. Using the selective SAC inhibitor, GsMTx-4, the role of these channels in mechanical hyperalgesia has been implicated [248]. Furthermore, similar to TRPV4, spinal intrathecal administration of antisense oligodeoxynucleotides to TRPC1 and TRPC6 reversed hyperalgesia to mechanical/hypotonic stimuli induced by inflammation [248]. Antisense to TRPC6, but not to TRPC1, reversed the mechanical hyperalgesia induced by a thermal injury or the TRPV4-selective agonist $4 \delta$-PDD suggesting different roles of these channels [248]. We suggest that TRPV4, TRPC6 and TRPC1 participate in mechanical hyperalgesia and primary afferent nociceptors sensitization. Moreover, TRPC6 emerges as an attractive candidate to transduce mechanical stimuli in the setting of inflammation or nerve injury.

TRPCs are involved in mediating the melittin-induced activation of different subpopulations of primary nociceptors [249]. TRPC channels are also involved in melittin-induced inflammatory nociceptive responses as studied using several behavioral models [249]. Pre- and post-administration of the TRPC antagonist SKF-96365 prevented and suppressed the nociceptive behavior. In addition, SKF-96365 had no effect on baseline threshold for either thermal or mechanical sensitivities [250]. TRPC channels, which are known as store-operated channels, are expressed in human osteoblasts cell lines and SaM-1 cells that may mediate nociceptive transmission in bone pain [251].

\section{CONCLUDING REMARKS}

Members of the TRP channel family are constantly being added to the list of nociceptive TRP channels as their relevance is revealed by their expression pattern, gene disruption studies and specific antagonists. Furthermore, in disease conditions over-expression of nociceptive TRP channels suggests the specific role of a TRP channel in a specific modality of pain. It is not well understood whether the type of TRP channel or its expression pattern is responsible for carrying a specific type of pain. But it appears that targeting a specific type of TRP channel can alleviate a specific type of pain. This idea has been elegantly demonstrated by targeting TRPV1, which selectively alleviates inflammatory thermal hypersensitivity without affecting mechanical hypersensitivity.

Several TRP channels have been suggested to play a role in mechanical pain sensitivity. Mechanical pain sensitivity involves allodynia and hyperalgesia, but the receptors that sense these modalities have not been clarified. Further, several TRP channels are expressed in the same nociceptor. This raises the question how does the interplay between TRP cannels in the same neuron come into picture during nociceptive transmission? It is also intriguing that interfering with any one of these TRP channels results in pain relief. Some of the nociceptive TRP channels are only expressed in primary afferent neurons, but neurotransmitters/neuropeptides released during neuronal activity in the spinal cord may alter the expression and function of receptors in higher order neurons and glia that could participate in nociceptive transmission as proposed in central sensitization. The role of the descending pathway as a result of enhanced primary afferent excitability has to be taken into consideration as well. It is likely that nociceptive and non-nociceptive receptors in primary afferent and higher order neurons function in concert, thereby when the threshold is crossed, painful sensation is perceived. As experimentally demonstrated, interfering with any one of these components that maintains the system below the threshold can induce pain relief. Therefore, it is not certain whether it can be claimed that the targeted receptor is the key component or one of many inter-related components that maintains the system under the threshold. Hence, the strategy is to affect multiple targets that may include other than nociceptive TRP channels by a single molecule or by multiple molecules or by non-drug strategies that maintains the system well below the threshold, so that subtle changes are not capable of initiating and maintaining nociceptive transmission resulting in painful episodes.

\section{CONFLICT OF INTEREST}

The authors confirm that this article content has no conflicts of interest. 


\section{ACKNOWLEDGEMENTS}

This work was supported by grants from National Institutes of Health (DA028017) and EAM award from SIUSOM. We thank Tsung-han Hsieh for comments on the manuscript.

\section{REFERENCES}

[1] Caterina MJ, Schumacher MA, Tominaga M, Rosen TA, Levine JD, Julius D. The capsaicin receptor: a heat-activated ion channel in the pain pathway. Nature 1997; 389 (6653): 816-24.

[2] Rutter AR, Ma QP, Leveridge M, Bonnert TP. Heteromerization and colocalization of TrpV1 and TrpV2 in mammalian cell lines and rat dorsal root ganglia. Neuroreport 2005; 16 (16): 1735-9.

[3] Smith GD, Gunthorpe MJ, Kelsell RE, et al. TRPV3 is a temperature-sensitive vanilloid receptor-like protein. Nature 2002; 418: $186-90$

[4] Liapi A, Wood JN. Extensive co-localization and heteromultimer formation of the vanilloid receptor-like protein TRPV2 and the capsaicin receptor TRPV1 in the adult rat cerebral cortex. Eur J Neurosci 2005; 22(4): 825-34.

[5] Premkumar LS, Bishnoi M. Disease-related changes in TRPV1 expression and its implications for drug development. Curr Top Med Chem 2011; 11(17): 2192-209

[6] Eid SR. Therapeutic targeting of TRP channels--the TR(i)P to pain relief. Curr Top Med Chem. 2011; 11(17): 2118-30.

[7] Nakatsuka T, Furue H, Yoshimura M, Gu JG. Activation of central terminal vanilloid receptor-1 receptors and alpha beta-methyleneATP-sensitive P2X receptors reveals a converged synaptic activity onto the deep dorsal horn neurons of the spinal cord. J Neurosci 2002; 22(4): 1228-37.

[8] Baccei ML, Bardoni R, Fitzgerald M. Development of nociceptive synaptic inputs to the neonatal rat dorsal horn: glutamate release by capsaicin and menthol. J Physiol 2003; 549(Pt 1): 231-42.

[9] Premkumar LS, Raisinghani M, Pingle SC, Long C, Pimentel F. Downregulation of transient receptor potential melastatin 8 by protein kinase C-mediated dephosphorylation. J Neurosci 2005; 25(49): 11322-29.

[10] Sikand P, Premkumar LS. Potentiation of glutamatergic synaptic transmission by protein kinase C-mediated sensitization of TRPV1 at the first sensory synapse. J Physiol 2007; 581: 631-47.

[11] Jeffry JA, Yu SQ, Sikand P, Parihar A, Evans MS, Premkumar LS. Selective targeting of TRPV1 expressing sensory nerve terminals in the spinal cord for long lasting analgesia. PLoS One 2009; 4(9): e7021.

[12] Dinh QT, Groneberg DA, Peiser C, et al. Substance P expression in TRPV1 and trkA-positive dorsal root ganglion neurons innervating the mouse lung. Respir Physiol Neurobiol 2004;144(1): 15-24.

[13] Lazzeri M, Spinelli M, Zanollo A, Turini D. Intravesical vanilloids and neurogenic incontinence: ten years experience. Urol Int 2004; 72(2): $145-9$.

[14] Venkatachalam K, Montell C. TRP channels. Annu Rev Biochem 2007; 76: 387-417.

[15] Peters JH, McDougall SJ, Fawley JA, Andresen MC. TRPV1 marks synaptic segregation of multiple convergent afferents at the rat medial solitary tract nucleus. PLoS One 2011; 6(9): e25015.

[16] Palazzo E, Luongo L, de Novellis V, Berrino L, Rossi F, Maione S. Moving towards supraspinal TRPV1 receptors for chronic pain relief. Mol Pain 2010; 6: 66

[17] Chavez AE, Chiu CQ, Castillo PE. TRPV1 activation by endogenous anandamide triggers postsynaptic long-term depression in dentate gyrus. Nat Neurosci 2010; 13(12): 1511-8.

[18] Grueter BA, Brasnjo G, Malenka RC. Postsynaptic TRPV1 triggers cell type-specific long-term depression in the nucleus accumbens. Nat Neurosci 2010; 13(12): 1519-25.

[19] Doyle MW, Bailey TW, Jin YH, Andresen MC. Vanilloid receptors presynaptically modulate cranial visceral afferent synaptic transmission in nucleus tractus solitarius. J Neurosci 2002; 22(18): $8222-9$.

[20] Marinelli S, Vaughan C, Christie MJ, Connor M. Capsaicin activation of glutamatergic synaptic transmission in the rat locus coeruleus in vitro. J Physiol 2002; 543(Pt 2): 531-40.

[21] Marinelli S, Di Marzo V, Berretta N, et al. Presynaptic facilitation of glutamatergic synapses to dopaminergic neurons of the rat substantia nigra by endogenous stimulation of vanilloid receptors. J Neurosci 2003; 23(8): 3136-44.

[22] Gibson HE, Edwards JG, Page RS, Van Hook MJ, Kauer JA. TRPV1 channels mediate long-term depression at synapses on hippocampal interneurons. Neuron 2008; 57 (5): 746-59.

[23] Mori F, Ribolsi M, Kusayanagi H, et al. TRPV1 channels regulate cortical excitability in humans. J Neurosci 2012; 32(3): 873-9.

[24] Cavanaugh DJ, Chesler AT, Jackson AC, et al. Trpv1 reporter mice reveal highly restricted brain distribution and functional expression in arteriolar smooth muscle cells. J Neurosci 2011; 31(13): 506777.

[25] Mishra SK, Tisel SM, Orestes P, Bhangoo SK, Hoon MA. TRPV1lineage neurons are required for thermal sensation. Embo J 2011; 30(3): 582-93.

[26] Caterina MJ, Leffler A, Malmberg AB, et al. Impaired nociception and pain sensation in mice lacking the capsaicin receptor. Science 2000; 288(5464): 306-13.

[27] Davis JB, Gray J, Gunthorpe MJ, et al. Vanilloid receptor-1 is essential for inflammatory thermal hyperalgesia. Nature 2000; 405(6783): 183-7.

[28] Szallasi A, Blumberg PM. Resiniferatoxin and its analogs provide novel insights into the pharmacology of the vanilloid (capsaicin) receptor. Life Sci 1990; 47(16): 1399-408

[29] Szallasi A, Blumberg PM. Specific binding of resiniferatoxin, an ultrapotent capsaicin analog, by dorsal root ganglion membranes. Brain Res 1990; 524(1): 106-11.

[30] Cuypers E, Yanagihara A, Karlsson E, Tytgat J. Jellyfish and other cnidarian envenomations cause pain by affecting TRPV1 channels. FEBS Lett 2006; 580(24): 5728-32.

[31] Siemens J, Zhou S, Piskorowski R, et al. Spider toxins activate the capsaicin receptor to produce inflammatory pain. Nature 2006 444(7116): 208-12.

[32] Zygmunt PM, Petersson J, Andersson DA, et al. Vanilloid receptors on sensory nerves mediate the vasodilator action of anandamide. Nature 1999; 400: 452-7.

[33] Ahern GP. Activation of TRPV1 by the satiety factor oleoylethanolamide. J Biol Chem 2003; 278: 30429-34.

[34] Ahern GP, Wang X, Miyares RL. Polyamines are potent ligands for the capsaicin receptor TRPV1. J Biol Chem 2006; 281(13): 8991-5.

[35] Puntambekar P, Van Buren J, Raisinghani M, Premkumar LS, Ramkumar V. Direct interaction of adenosine with the TRPV1 channel protein. J Neurosci 2004; 24(14): 3663-71.

[36] Sugiura T, Tominaga M, Katsuya H, Mizumura K. Bradykinin lowers the threshold temperature for heat activation of vanilloid receptor 1. J Neurophysiol 2002; 88(1): 544-8.

[37] Zhu W, Xu P, Cuascut FX, Hall AK, Oxford GS. Activin acutely sensitizes dorsal root ganglion neurons and induces hyperalgesia via PKC-mediated potentiation of transient receptor potential vanilloid I. J Neurosci 2007; 27(50): 13770-80.

[38] Tominaga M, Wada M, Masu M. Potentiation of capsaicin receptor activity by metabotropic ATP receptors as a possible mechanism for ATP-evoked pain and hyperalgesia. Proc Natl Acad Sci USA 2001; 98: 6951-6.

[39] Kress M, Guenther, S. Role of $\left[\mathrm{Ca}^{2+}\right] \mathrm{i}$ in the ATP-induced heat sensitization process of rat nociceptive neurons. J Neurophysiol 1999; 81(6): 2612-9.

[40] Kwak J, Wang MH, Hwang SW, Kim TY, Lee SY, Oh U. Intracellular ATP increases capsaicin-activated channel activity by interacting with nucleotide-binding domains. J Neurosci 2000 20(22): 8298-304.

[41] Cesare P, McNaughton P. A novel heat-activated current in nociceptive neurons and its sensitization by bradykinin. Proc Natl Acad Sci U S A 1996; 93(26): 15435-9.

[42] Premkumar LS, Ahern GP. Induction of vanilloid receptor channel activity by protein kinase C. Nature 2000; 408(6815): $985-90$.

[43] Hu HJ, Bhave G, Gereau RW $4^{\text {th }}$. Prostaglandin and protein kinase A-dependent modulation of vanilloid receptor function by metabotropic glutamate receptor 5: potential mechanism for thermal hyperalgesia. J Neurosci 2002; 22(17): 7444-52.

[44] Kim BM, Lee SH, Shim WS, Oh, U. Histamine-induced $\mathrm{Ca}^{(2+)}$ influx via the PLA(2)/lipoxygenase/TRPV1 pathway in rat sensory neurons. Neurosci Lett 2004; 361(1-3): 159-62.

[45] Dai Y, Moriyama T, Higashi T, et al. Proteinase-activated receptor 2-mediated potentiation of transient receptor potential vanilloid subfamily 1 activity reveals a mechanism for proteinase-induced inflammatory pain. J Neurosci 2004; 24(18): 4293-9. 
[46] Sugiuar T, Bielefeldt K, Gebhart GF. TRPV1 function in mouse colon sensory neurons is enhanced by metabotropic 5hydroxytryptamine receptor activation. J Neurosci 2004; 24(43): 9521-30.

[47] Amadesi S, Nie J, Vergnolle N, et al. Protease-activated receptor 2 sensitizes the capsaicin receptor transient receptor potential vanilloid receptor 1 to induce hyperalgesia. J Neurosci 2004; 24(18): 4300-12.

[48] Donnerer J, Liebmann I, Schicho R. Differential regulation of 3beta-hydroxysteroid dehydrogenase and vanilloid receptor TRPV1 mRNA in sensory neurons by capsaicin and NGF. Pharmacology 2005; 73(2): 97-101.

[49] Stein AT, Ufret-Vincenty CA, Hua L, Santana LF, Gordon SE. Phosphoinositide 3-kinase binds to TRPV1 and mediates NGFstimulated TRPV1 trafficking to the plasma membrane. J Gen Physiol 2006; 128(5): 509-22.

[50] Amaya F, Shimosato G, Nagano M, et al. NGF and GDNF differentially regulate TRPV1 expression that contributes to development of inflammatory thermal hyperalgesia. Eur J Neurosci 2004; 20(9): 2303-10.

[51] Van Buren JJ, Bhat S, Rotello R, Pauza ME, Premkumar LS. Sensitization and translocation of TRPV1 by insulin and IGF-I. Mol Pain 2005; 1: 17.

[52] Sathianathan V, Avelino A, Charrua A, et al. Insulin induces cobalt uptake in a subpopulation of rat cultured primary sensory neurons. Eur J Neurosci 2003; 18(9): 2477-86.

[53] Raisinghani M, Pabbidi RM, Premkumar LS. Activation of transient receptor potential vanilloid 1 (TRPV1) by resiniferatoxin. J Physiol 2005; 567: 771-86.

[54] Bishnoi M, Bosgraaf CA, Premkumar LS. Preservation of acute pain and efferent functions following intrathecal resiniferatoxininduced analgesia in rats. J Pain 2011; 12(9): 991-1003.

[55] Gunthorpe MJ, Hannan SL, Smart D, et al. Characterization of SB705498, a potent and selective vanilloid receptor-1 (VR1/TRPV1) antagonist that inhibits the capsaicin-, acid-, and heat-mediated activation of the receptor. J Pharmacol Exp Ther 2007; 321(3): 1183-92.

[56] Lappin SC, Randall AD, Gunthorpe MJ, Morisset V. TRPV1 antagonist, SB-366791, inhibits glutamatergic synaptic transmission in rat spinal dorsal horn following peripheral inflammation. Eur J Pharmacol 2006; 540: 73-81.

[57] Westaway SM, Chung YK, Stevens AJ, Thompson M. NTetrahydroquinolinyl, N-quinolinyl andN-isoquinolinyl biaryl carboxamides as antagonists of TRPV1. Bioorg Med Chem Lett 2006; 16: 4533-6.

[58] Brown BS, Keddy R, Zheng GZ, Schmidt RG, McDonald HA, Bianchi BR. Tetrahydropyridine-4-carboxamides as novel, potent transient receptor potential vanilloid 1 (TRPV1) antagonists, Bioorg Med Chem Lett 2008; 16: 8516-25.

[59] El Kouhen R, Surowy CS, Bianchi BR, et al. A- 425619 [1isoquinolin-5-yl-3-(4-trifluoromethyl-benzyl)-urea], a novel and selective transient receptor potential type V1 receptor antagonist, blocks channel activation by vanilloids, heat, and acid. J Pharmacol Exp Ther 2005; 314: 400-9.

[60] McDonald HA, Neelands TR, Kort M, Han P, Vos MH, Faltynek CR. Characterization of A-425619 at native TRPV1 receptors: a comarison between dorsal root ganglia and trigeminal ganglia. Eur J Pharmacol 2008; 596: 62-9.

[61] Cui M, Honore P, Zhong C, et al. TRPV1 receptors in the CNS play a key role in broad-spectrum analgesia of TRPV1 antagonists. J Neurosci 2006; 26: 9385-93.

[62] Szallasi A, Cortright DN, Blum CA, Eid SR. The vanilloid receptor TRPV1: 10 years from channel cloning to antagonist proof-ofconcept. Nat Rev Drug Discov 2007; 6(5): 357-72.

[63] Wu C, Gavva NR, Brennan TJ. Effect of AMG0347, a transient receptor potentioal type V1 receptor antagonist, and morphine on pain behaviour after platarincision, Anesthesiology 2008; 108: 1100-8.

[64] Bishnoi M, Premkumar LS. Possible consequences of blocking transient receptor potential vanilloid. Curr Pharm Biotechnol 2011; 12(1): 102-14

[65] Park CK, Xu ZZ, Liu T, Lü N, Serhan CN, Ji RR. Resolvin D2 is a potent endogenous inhibitor for transient receptor potential subtype V1/A1, inflammatory pain, and spinal cord synaptic plasticity in mice: distinct roles of resolvin D1, D2, and E1. J Neurosci 2011; 31(50): 18433-8.
[66] Park CK, Lü N, Xu ZZ, Liu T, Serhan CN, Ji RR. Resolving TRPV1- and TNF- $\alpha$-mediated spinal cord synaptic plasticity and inflammatory pain with neuroprotectin D1. J Neurosci 2011; 31(42): 15072-85.

[67] Apostolidis A, Brady CM, Yiangou Y, Davis J, Fowler CJ, Anand P. Capsaicin receptor TRPV1 in urothelium of neurogenic human bladders and effect of intravesical resiniferatoxin. Urology 2005: 65(2): 400-5.

[68] Giannantoni A, Mearini E, Di Stasi SM, et al. New therapeutic options for refractory neurogenic detrusor overactivity. Minerva Urol Nefrol 2004; 56(1): 79-87.

[69] Petersen KL, Rice FL, Suess F, Berro M, Rowbotham MC. Relief of post-herpetic neuralgia by surgical removal of painful skin. Pain 2002; 98(1-2): 119-26.

[70] Lauria G, Morbin M, Lombardi R, et al. Expression of capsaicin receptor immunoreactivity in human peripheral nervous system and in painful neuropathies. J Peripher Nerv Syst 2006; 11(3): 262-71.

[71] Akerman S, Kaube H, Goadsby PJ. Anandamide acts as a vasodilator of dural blood vessels in vivo by activating TRPV1 receptors. Br J Pharmacol 2004; 142(8): 1354-60.

[72] Ghilardi JR, Rohrich H, Lindsay TH, et al. Selective blockade of the capsaicin receptor TRPV1 attenuates bone cancer pain. J Neurosci 2005; 25: 3126-31.

[73] Immke DC, Gavva NR. The TRPV1 receptor and nociception. Semin Cell Dev Biol 2006; 17(5): 582-91.

[74] Khairatkar-Joshi N, Szallasi A. TRPV1 antagonists: the challenges for therapeutic targeting. Trends Mol Med 2009; 15(1): 14-22.

[75] Varga A, Németh J, Szabó A, et al. Effects of the novel TRPV1 receptor antagonist SB366791 in vitro and in vivo in the rat. Neurosci Lett 2005; 385(2): 137-42.

[76] Gavva NR, Treanor JJ, Garami A, et al. Pharmacological blockade of the vanilloid receptor TRPV1 elicits marked hyperthermia in humans. Pain 2008; 136(1-2): 202-10.

[77] Lehto SG, Tamir R, Deng H, et al. Antihyperalgesic effects of (R,E)-N-(2-hydroxy-2,3-dihydro-1H-inden-4-yl)-3-(2-(piperidin-1yl)-4-(trifluoromethyl)phenyl)-acrylamide (AMG8562), a novel transient receptor potential vanilloid type 1 modulator that does not cause hyperthermia in rats. J Pharmacol Exp Ther 2008; 326(1): 218-29.

[78] Caterina MJ, Rosen TA, Tominaga M, Brake AJ, Julius D. A capsaicin-receptor homologue with a high threshold for noxious heat. Nature 1999; 398(6726): 436-41.

[79] Montell C, Birnbaumer L, Flockerzi V. The TRP channels, a remarkably functional family. Cell 2002; 108 (5): 595-8.

[80] Neeper MP, Liu Y, Hutchinson TL, Wang Y, Flores CM, Qin N. Activation properties of heterologously expressed mammalian TRPV2: evidence for species dependence. J Biol Chem 2007; 282(21): 15894-902.

[81] Bang S, Kim KY, Yoo S, Lee SH, Hwang SW. Transient receptor potential V2 expressed in sensory neurons is activated by probenecid. Neurosci Lett 2007; 425(2): 120-5.

[82] Iwata Y, Katanosaka Y, Arai Y, Komamura K, Miyatake K, Shigekawa M. A novel mechanism of myocyte degeneration involving the $\mathrm{Ca}^{2+}$-permeable growth factor-regulated channel. J Cell Biol 2003; 161(5): 957-67.

[83] Muraki K, Iwata Y, Katanosaka Y, et al. TRPV2 is a component of osmotically sensitive cation channels in murine aortic myocytes. Circ Res 2003; 93(9): 829-38.

[84] Ahluwalia J, Rang H, Nagy I. The putative role of vanilloid receptor-like protein-1 in mediating high threshold noxious heatsensitivity in rat cultured primary sensory neurons. Eur J Neurosci 2002; 16(8): 1483-9

[85] Ichikawa $\mathrm{H}$, Sugimoto $\mathrm{T}$. The difference of osteocalcinimmunoreactive neurons in the rat dorsal root and trigeminal ganglia: co-expression with nociceptive transducers and central projection. Brain Res 2002; 958(2): 459-62.

[86] Lewinter RD, Skinner K, Julius D, Basbaum AI. Immunoreactive TRPV-2 (VRL-1), a capsaicin receptor homolog, in the spinal cord of the rat. J Comp Neurol 2004; 470(4): 400-8.

[87] Zhang L, Jones S, Brody K, Costa M, Brookes SJ. Thermosensitive transient receptor potential channels in vagal afferent neurons of the mouse. Am J Physiol Gastrointest Liver Physiol 2004; 286(6): G983-91.

[88] Malcangio M, Garrett NE, Cruwys S, Tomlinson DR. Nerve growth factor- and neurotrophin-3-induced changes in nociceptive 
threshold and the release of substance $\mathrm{P}$ from the rat isolated spinal cord. J Neurosci 1997; 17(21): 8459-67.

[89] Shu XQ, Llinas A, Mendell LM. Effects of trkB and trkC neurotrophin receptor agonists on thermal nociception: a behavioral and electrophysiological study. Pain 1999; 80(3): 463-70.

[90] Schroder HD. Somatostatin in the caudal spinal cord: an immunohistochemical study of the spinal centers involved in the innervation of pelvic organs. J Comp Neurol 1984; 223(3): 400-14.

[91] McKenna KE, Nadelhaft I. The organization of the pudendal nerve in the male and female rat. J Comp Neurol 1986; 248(4): 532-49.

[92] Kashiba H, Uchida Y, Takeda D, et al. TRPV2-immunoreactive intrinsic neurons in the rat intestine. Neurosci Lett 2004; 366(2): 193-6.

[93] Okano H, Koike S, Bamba H, Toyoda K, Uno T, Hisa Y. Participation of TRPV1 and TRPV2 in the rat laryngeal sensory innervation. Neurosci Lett 2006; 400(1-2): 35-8.

[94] Kanzaki M, Zhang YQ, Mashima H, Li L, Shibata H, Kojima I. Translocation of a calcium-permeable cation channel induced by insulin-like growth factor-I. Nat Cell Biol 1999; 1(3): 165-70.

[95] Boels K, Glassmeier G, Herrmann D, et al. The neuropeptide head activator induces activation and translocation of the growth-factorregulated $\mathrm{Ca}(2+)$-permeable channel GRC. J Cell Sci 2001; 114: 3599-606.

[96] Penna A, Juvin V, Chemin J, Compan V, Monet M, Rassendren FA. PI3-kinase promotes TRPV2 activity independently of channel translocation to the plasma membrane. Cell Calcium 2006; 39(6): 495-507.

[97] Stokes AJ, Shimoda LM, Koblan-Huberson M, Adra CN, Turner H. A TRPV2-PKA signaling module for transduction of physical stimuli in mast cells. J Exp Med 2004; 200 (2): 137-47.

[98] Cavanaugh DJ, Lee H, Lo L, et al. Distinct subsets of unmyelinated primary sensory fibers mediate behavioral responses to noxious thermal and mechanical stimuli. Proc Natl Acad Sci U S A 2009; 106(22): 9075-80.

[99] Mishra SK, Hoon MA. Ablation of TrpV1 neurons reveals their selective role in thermal pain sensation. Mol Cell Neurosci 2010; 43(1): 157-63.

[100] Park U, Vastani N, Guan Y, Raja SN, Koltzenburg M, Caterina MJ. TRP vanilloid 2 knock-out mice are susceptible to perinatal lethality but display normal thermal and mechanical nociception. $\mathbf{J}$ Neurosci 2011; 31(32): 11425-36.

[101] Axelsson HE, Minde JK, Sonesson A, Toolanen G, Högestätt ED, Zygmunt PM. Transient receptor potential vanilloid 1, vanilloid 2 and melastatin 8 immunoreactive nerve fibers in human skin from individuals with and without Norrbottnian congenital insensitivity to pain. Neuroscience 2009; 162(4): 1322-32.

[102] Son AR, Yang YM, Hong JH, Lee SI, Shibukawa Y, Shin DM. Odontoblast TRP channels and thermo/mechanical transmission. J Dent Res 2009; 88(11): 1014-9.

[103] Gibbs JL, Melnyk JL, Basbaum AI. Differential TRPV1 and TRPV2 channel expression in dental pulp. J Dent Res 2011; 90(6): 765-70.

[104] Shibasaki K, Murayama N, Ono K, Ishizaki Y, Tominaga M. TRPV2 enhances axon outgrowth through its activation by membrane stretch in developing sensory and motor neurons. J Neurosci 2010; 30(13): 4601-12.

[105] Birnbaumer L, Yildirim E, Abramowitz J. A comparison of the genes coding for canonical TRP channels and their M, V and P relatives. Cell Calcium 2003; 33(5-6): 419-32.

[106] Moqrich A, Hwang SW, Earley TJ, et al. Impaired thermosensation in mice lacking TRPV3, a heat and camphor sensor in the skin. Science 2005; 307(5714): 1468-72.

[107] Hu H, Grandl J, Bandell M, Petrus M, Patapoutian A. Two amino acid residues determine 2-APB sensitivity of the ion channels TRPV3 and TRPV4. Proc Natl Acad Sci U S A 2009; 106(5): 1626-31.

[108] Smith GD, Gunthorpe MJ, Kelsell RE, et al. TRPV3 is a temperature-sensitive vanilloid receptor-like protein. Nature 2002; 418(6894): 186-90.

[109] Huang SM, Lee H, Chung MK, et al. Overexpressed transient receptor potential vanilloid 3 ion channels in skin keratinocytes modulate pain sensitivity via prostaglandin E2. J Neurosci 2008; 28(51): 13727-37.

[110] Hammarstrom S, Hamberg M, Samuelsson B, Duell EA, Stawiski $\mathrm{M}$, Voorhees JJ. Increased concentrations of nonesterified arachidonic acid, 12L-hydroxy-5,8,10,14-eicosatetraenoic acid, prostaglandin E2, and prostaglandin F2alpha in epidermis of psoriasis. Proc Natl Acad Sci U S A 1975; 72(12): 5130-4.

[111] Brash AR. Arachidonic acid as a bioactive molecule. J Clin Invest 2001; 107 (11): 1339-45.

[112] Hu HZ, Xiao R, Wang C, Gao N, Colton CK, Wood JD, Zhu MX. Potentiation of TRPV 3 channel function by unsaturated fatty acids. J Cell Physiol 2006; 208(1): 201-12.

[113] Xu H, Delling M, Jun JC, Clapham DE. Oregano, thyme and clovederived flavors and skin sensitizers activate specific TRP channels. Nat Neurosci 2006; 9(5): 628-35.

[114] Xiao R, Tang J, Wang C, Colton CK, Tian J, Zhu MX. Calcium plays a central role in the sensitization of TRPV3 channel to repetitive stimulations. J Biol Chem 2008; 283 (10): 6162-74.

[115] Mandadi S, Sokabe T, Shibasaki K, et al. TRPV3 in keratinocytes transmits temperature information to sensory neurons via ATP. Pflugers Arch 2009; 458(6): 1093-102.

[116] Gopinath P, Wan E, Holdcroft A, et al. Increased capsaicin receptor TRPV1 in skin nerve fibres and related vanilloid receptors TRPV3 and TRPV4 in keratinocytes in human breast pain. BMC Womens Health 2005; 5(1): 2.

[117] Facer P, Casula MA, Smith GD, et al. Differential expression of the capsaicin receptor TRPV1 and related novel receptors TRPV3, TRPV4 and TRPM8 in normal human tissues and changes in traumatic and diabetic neuropathy. BMC Neurol 2007; 7: 11 .

[118] Frederick J, Buck ME, Matson DJ, Cortright DN. Increased TRPA1, TRPM8, and TRPV2 expression in dorsal root ganglia by nerve injury. Biochem Biophys Res Commun 2007; 358(4): 105864 .

[119] Khairatkar-Joshi N, Maharaj, N, Thomas A. The TRPV3 recepotor as a pain terget: A therapeutic promise or just some more new bilogy. Open Drug Discovery J 2010; 2: 89-97.

[120] Steenland HW, Ko SW, Wu LJ, Zhuo M. Hot receptors in the brain. Mol Pain 2006; 2: 34 .

[121] Gullapalli S. GRC 15133 is a TRPV3 selective antagonist with moderate antagonistic potency. World Pharmaceutical Congress, Philadelphia, PA, USA. May 12-13, 2008.

[122] Chong JFC, Larsen GR, Lumma Jr, et al. Compounds for modulating TRPV3. Function., May 18, 2007.

[123] Reilly RM, Kym PR. Analgesic potential of TRPV3 antagonists. Curr Top Med Chem 2011; 11(17): 2210-15.

[124] Imura K, Yoshioka T, Hikita I, et al. Influence of TRPV3 mutation on hair growth cycle in mice. Biochem Biophys Res Commun 2007; 363(3): 479-83.

[125] Asakawa M, Yoshioka T, Matsutani T, et al. Association of a mutation in TRPV3 with defective hair growth in rodents. J Invest Dermatol 2006; 126(12): 2664-72.

[126] Strotmann R, Harteneck C, Nunnenmacher K, Schultz G, Plant TD. OTRPC4, a nonselective cation channel that confers sensitivity to extracellular osmolarity. Nat Cell Biol 2000; 2(10): 695-702.

[127] Watanabe H, Davis JB, Smart D, et al. Activation of TRPV4 channels (hVRL-2/mTRP12) by phorbol derivatives. J Biol Chem 2002; 277(16): 13569-77.

[128] Suzuki M, Mizuno A, Kodaira K, Imai M. Impaired pressure sensation in mice lacking TRPV4. J Biol Chem 2003; 278(25): 22664-8.

[129] Nilius B, Droogmans G, Wondergem R. Transient receptor potential channels in endothelium: solving the calcium entry puzzle? Endothelium 2003; 10(1): 5-15.

[130] Cohen DM. TRPV4 and the mammalian kidney. Pflugers Arch 2005; 451(1): 168-75.

[131] Gao X, Wu L, O'Neil RG. Temperature-modulated diversity of TRPV4 channel gating: activation by physical stresses and phorbol ester derivatives through protein kinase $\mathrm{C}$-dependent and independent pathways. J Biol Chem 2003; 278(29): 27129-37.

[132] O'Neil RG, Heller S. The mechanosensitive nature of TRPV channels. Pflugers Arch 2005; 451(1): 193-203.

[133] Kohler R, Heyken WT, Heinau P, et al. Evidence for a functional role of endothelial transient receptor potential V4 in shear stressinduced vasodilatation. Arterioscler Thromb Vasc Biol 2006; 26(7): 1495-502.

[134] Watanabe H, Vriens J, Suh SH, Benham CD, Droogmans G, Nilius B. Heat-evoked activation of TRPV4 channels in a HEK293 cell expression system and in native mouse aorta endothelial cells. J Biol Chem 2002; 277(49): 47044-51. 
[135] Watanabe H, Vriens J, Prenen J, Droogmans G, Voets T, Nilius B. Anandamide and arachidonic acid use epoxyeicosatrienoic acids to activate TRPV4 channels. Nature 2003; 424(6947): 434-8.

[136] Drew LJ, Rohrer DK, Price MP, et al. Acid-sensing ion channels ASIC2 and ASIC3 do not contribute to mechanically activated currents in mammalian sensory neurones. J Physiol 2004; 556(Pt 3): 691-710.

[137] Loukin SH, Su Z, Kung C. Hypotonic shocks activate rat TRPV4 in yeast in the absence of polyunsaturated fatty acids. FEBS Lett 2009; 583(4): 754-8.

[138] Cao DS, Yu SQ, Premkumar LS. Modulation of transient receptor potential Vanilloid 4-mediated membrane currents and synaptic transmission by protein kinase C. Mol Pain 2009; $5: 5$.

[139] Matthews BD, Thodeti CK, Tytell JD, Mammoto A, Overby DR, Ingber DE. Ultra-rapid activation of TRPV4 ion channels by mechanical forces applied to cell surface betal integrins. Integr Biol (Camb) 2010; 2(9): 435-42.

[140] Alessandri-Haber N, Yeh JJ, Boyd AE, et al. Hypotonicity induces TRPV4-mediated nociception in rat. Neuron 2003; 39(3): 497-511.

[141] Alessandri-Haber N, Joseph E, Dina OA, Liedtke W, Levine JD. TRPV4 mediates pain-related behavior induced by mild hypertonic stimuli in the presence of inflammatory mediator. Pain 2005; 118(1-2): 70-9.

[142] Alessandri-Haber N, Dina OA, Joseph EK, Reichling DB, Levine JD. Interaction of transient receptor potential vanilloid 4, integrin, and SRC tyrosine kinase in mechanical hyperalgesia. J Neurosci 2008; 28(5): 1046-57.

[143] Ceppa E, Cattaruzza F, Lyo V, et al. Transient receptor potential ion channels V4 and A1 contribute to pancreatitis pain in mice. Am J Physiol Gastrointest Liver Physiol 2010; 299(3): G556-71.

[144] Chen X, Alessandri-Haber N, Levine JD. Marked attenuation of inflammatory mediator-induced C-fiber sensitization for mechanical and hypotonic stimuli in TRPV4-/- mice. Mol Pain 2007; $3: 31$.

[145] Chen Y, Yang C, Wang ZJ. Proteinase-activated receptor 2 sensitizes transient receptor potential vanilloid 1 , transient receptor potential vanilloid 4, and transient receptor potential ankyrin 1 in paclitaxel-induced neuropathic pain. Neuroscience 2011; 193: 44051.

[146] Ding XL, Wang YH, Ning LP, et al. Involvement of TRPV4-NOcGMP-PKG pathways in the development of thermal hyperalgesia following chronic compression of the dorsal root ganglion in rats. Behav Brain Res 2010; 208(1): 194-201.

[147] Wang C, Ning LP, Wang YH, et al. Nuclear factor-kappa B mediates TRPV4-NO pathway involved in thermal hyperalgesia following chronic compression of the dorsal root ganglion in rats. Behav Brain Res 2011;221(1): 19-24.

[148] Wei X, Edelmayer RM, Yan J, Dussor G. Activation of TRPV4 on dural afferents produces headache-related behavior in a preclinical rat model. Cephalalgia 2011; 31(16): 1595-600.

[149] Kochukov MY, McNearney TA, Yin H, et al. Tumor necrosis factor-alpha (TNF-alpha) enhances functional thermal and chemical responses of TRP cation channels in human synoviocytes. Mol Pain 2009; 5: 49.

[150] TRPV4 agonists and antagonists.Vincent F, Duncton MA. Curr Top Med Chem 2011; 11(17): 2216-26.

[151] Bang S, Yang TJ, Yoo S, Heo TH, Hwang SW. Inhibition of sensory neuronal TRPs contributes to anti-nociception by butamben. Neurosci Lett 2012; 506(2): 297-302.

[152] Bang S, Yoo S, Yang T, Cho H, Hwang S. Nociceptive and proinflammatory effects of dimethylallyl pyrophosphate via TRPV4 activation. Br J Pharmacol 2012; 166: 1433-43.

[153] Jaquemar D, Schenker T, Trueb B. An ankyrin-like protein with transmembrane domains is specifically lost after oncogenic transformation of human fibroblasts. J Biol Chem 1999; 274(11): 7325-33.

[154] Story GM, Peier AM, Reeve AJ, et al. ANKTM1, a TRP-like channel expressed in nociceptive neurons, is activated by cold temperatures. Cell 2003; 112(6): 819-29.

[155] Sotomayor M, Corey DP, Schulten K. In search of the hair-cell gating spring elastic properties of ankyrin and cadherin repeats. Structure 2005 ; 13(4): 669-82.

[156] Corey DP, Garcia-Anoveros J, Holt JR, et al. TRPA1 is a candidate for the mechanosensitive transduction channel of vertebrate hair cells. Nature 2004; 432(7018): 723-30.
[157] Nagata K, Duggan A, Kumar G, Garcia-Anoveros J. Nociceptor and hair cell transducer properties of TRPA1, a channel for pain and hearing. J Neurosci 2005; 25 (16): 4052-61.

[158] Smith MP, Beacham D, Ensor E, Koltzenburg M. Cold-sensitive, menthol-insensitive neurons in the murine sympathetic nervous system. Neuroreport 2004; 15(9): 1399-403.

[159] Katsura H, Tsuzuki K, Noguchi K, Sakagami M. Differential expression of capsaicin-, menthol-, and mustard oil-sensitive receptors in naive rat geniculate ganglion neurons. Chem Senses 2006; 31(7): 681-8.

[160] Andrade EL, Meotti FC, Calixto JB. TRPA1 antagonists as potential analgesic drugs. Pharmacol Ther 2012; 133(2): 189-204.

[161] Bandell M, Story GM, Hwang SW, et al. Noxious cold ion channel TRPA1 is activated by pungent compounds and bradykinin. Neuron 2004; 41(6): 849-57.

[162] Obata K, Katsura H, Mizushima T, et al. TRPA1 induced in sensory neurons contributes to cold hyperalgesia after inflammation and nerve injury. J Clin Invest 2005; 115(9): 2393401.

[163] Allchorne AJ, Broom DC, Woolf CJ. Detection of cold pain, cold allodynia and cold hyperalgesia in freely behaving rats. Mol Pain 2005; $1: 36$.

[164] Bautista DM, Siemens J, Glazer JM, et al. The menthol receptor TRPM8 is the principal detector of environmental cold. Nature 2007; 448(7150): 204-8

[165] Cao D-S, Zhong L, Hsieh TH, et al. Expression of Transient Receptor Potential Ankyrin 1 (TRPA1) and its role in insulin release from rat pancreatic beta cells. PLoS One 2012 (in press).

[166] Jordt SE, Bautista DM, Chuang HH, et al. Mustard oils and cannabinoids excite sensory nerve fibres through the TRP channel ANKTM1. Nature 2004; 427(6971): 260-5.

[167] Bautista DM, Jordt SE, Nikai T, et al. TRPA1 mediates the inflammatory actions of environmental irritants and proalgesic agents. Cell 2006; 124(6): 1269-82.

[168] Macpherson LJ, Geierstanger BH, Viswanath V, et al. The pungency of garlic: activation of TRPA1 and TRPV1 in response to allicin. Curr Biol 2005; 15(10): 929-34.

[169] Hinman A, Chuang HH, Bautista DM, Julius D. TRP channel activation by reversible covalent modification. Proc Natl Acad Sci USA 2006; 103(51): 19564-8.

[170] Andersson DA, Gentry C, Alenmyr L, et al. TRPA1 mediates spinal antinociception induced by acetaminophen and the cannabinoid $\Delta(9)$-tetrahydrocannabiorcol. Nat Commun 2011; 22(2): 551

[171] Raisinghani M, Zhong L, Jeffry JA, et al. Activation characteristics of transient receptor potential ankyrin 1 and its role in nociception. Am J Physiol Cell Physiol 2011; 301(3): C587-600.

[172] Peier AM, Reeve AJ, Andersson DA, et al. A heat-sensitive TRP channel expressed in keratinocytes. Science 2002; 296(5575): 2046-9.

[173] Andersson DA, Gentry C, Moss S, Bevan S. Transient receptor potential A1 is a sensory receptor for multiple products of oxidative stress. J Neurosci 2008; 28(10): 2485-94.

[174] Bessac BF, Sivula M, von Hehn CA, Escalera J, Cohn L, Jordt SE. TRPA1 is a major oxidant sensor in murine airway sensory neurons. J Clin Invest 2008; 118(5): 1899-910.

[175] Okubo K, Matsumura M, Kawaishi Y, et al. Hydrogen sulfideinduced mechanical hyperalgesia and allodynia require activation of both $\mathrm{Ca}(\mathrm{v}) 3.2$ and TRPA1 channels in mice. Br J Pharmacol 2012 Feb 2. doi: $10.1111 /$ j.1476-5381.

[176] Tracey WD Jr., Wilson RI, Laurent G, Benzer S. Painless, a Drosophila gene essential for nociception. Cell 2003; 113(2): 26173.

[177] Bautista DM, Movahed P, Hinman A, et al. Pungent products from garlic activate the sensory ion channel TRPA1. Proc Natl Acad Sci U S A 2005; 102(34): 12248-52.

[178] Kwan KY, Allchorne AJ, Vollrath MA, Christensen AP, Zhang DS, Woolf CJ, Corey DP. TRPA1 contributes to cold, mechanical, and chemical nociception but is not essential for hair-cell transduction. Neuron 2006; 50(2): 277-89.

[179] Taylor-Clark TE, Undem BJ, Macglashan DW Jr, Ghatta S, Carr MJ, McAlexander MA. Prostaglandin-induced activation of nociceptive neurons via direct interaction with transient receptor potential A1 (TRPA1). Mol Pharmacol 2008; 73(2): 274-81.

[180] Levine JD, Alessandri-Haber N. TRP channels: Targets for the relief of pain. Biochim Biophys Acta 2007; 1772: 989-1003 
[181] Rech JC, Eckert WA, Maher MP, Banke T, Bhattacharya A, Wickenden AD. Recent advances in the biology and medicinal chemistry of TRPA1. Future Med Chem 2010; 2(5): 843-58.

[182] Jiang LH, Gamper N, Beech DJ. Properties and therapeutic potential of transient receptor potential channels with putative roles in adversity: focus on TRPC5, TRPM2 and TRPA1. Curr Drug Targets 2011; 12(5): 724-36.

[183] Eid SR, Crown ED, Moore EL, et al. HC-030031, a TRPA1 selective antagonist, attenuates inflammatory- and neuropathyinduced mechanical hypersensitivity. Mol Pain 2008; 4: 48.

[184] Wei H, Hämäläinen MM, Saarnilehto M, Koivisto A, Pertovaara A.Attenuation of mechanical hypersensitivity by an antagonist of the TRPA1 ion channel in diabetic animals. Anesthesiology 2009; 111(1): 147-54.

[185] Chen J, Joshi SK, DiDomenico S, et al. Selective blockade of TRPA1 channel attenuates pathological pain without altering noxious cold sensation or body temperature regulation. Pain 2011; 152(5): 1165-72.

[186] Moran MM, McAlexander MA, Bíró T, Szallasi A. Transient receptor potential channels as therapeutic targets. Nat Rev Drug Discov 2011; 10(8): 601-20.

[187] Kremeyer B, Lopera F, Cox JJ, et al. A gain- of-function mutation in TRPA1 causes familial episodic pain syndrome. Neuron 2010; 66: 671-80.

[188] Nagamine K, Kudoh J, Minoshima S, et al. Molecular cloning of a novel putative $\mathrm{Ca} 2+$ channel protein (TRPC7) highly expressed in brain. Genomics 1998; 54(1): 124-31.

[189] Perraud AL, Fleig A, Dunn CA, et al. ADP-ribose gating of the calcium-permeable LTRPC2 channel revealed by Nudix motif homology. Nature 2001; 411(6837): 595-9.

[190] Mei ZZ, Xia R, Beech DJ, Jiang LH. Intracellular coiled-coil domain engaged in subunit interaction and assembly of melastatin related transient receptor potential channel 2. J Biol Chem 2006; 281(50): 38748-56.

[191] Sano Y, Inamura K, Miyake A, et al. Immunocyte Ca2+ influx system mediated by LTRPC2. Science 2001; 293(5533): 1327-30.

[192] Grubisha O, Rafty LA, Takanishi CL, et al. Metabolite of SIR2 reaction modulates TRPM2 ion channel. J Biol Chem 2006; 281(20): 14057-65.

[193] Togashi K, Hara Y, Tominaga T, et al. TRPM2 activation by cyclic ADP-ribose at body temperature is involved in insulin secretion. EMBO J 2006; 25(9): 1804-15.

[194] Kraft R, Grimm C, Grosse K, et al. Hydrogen peroxide and ADPribose induce TRPM2-mediated calcium influx and cation currents in microglia. Am J Physiol Cell Physiol 2004; 286(1): C129-37.

[195] Dietrich A, Gudermann T. Another TRP to endothelial dysfunction: TRPM2 and endothelial permeability. Circ Res 2008; 102(3): 2757.

[196] Yamamoto S, Shimizu S, Kiyonaka S, et al. TRPM2-mediated $\mathrm{Ca} 2+$ influx induces chemokine production in monocytes that aggravates inflammatory neutrophil infiltration. Nat Med 2008; 14(7): 738-47.

[197] Hill K, Tigue NJ, Kelsell RE, et al. Characterisation of recombinant rat TRPM2 and a TRPM2-like conductance in cultured rat striatal neurones. Neuropharmacology 2006; 50(1): 8997.

[198] Yamamoto S, Wajima T, Hara Y, Nishida M, Mori Y. Transient receptor potential channels in Alzheimer's disease. Biochim Biophys Acta 2007; 1772(8): 958-67.

[199] Fonfria E, Marshall IC, Boyfield I, et al. Amyloid beta-peptide(142) and hydrogen peroxide-induced toxicity are mediated by TRPM2 in rat primary striatal cultures. J Neurochem 2005; 95(3): 715-23.

[200] Hermosura MC, Cui AM, Go RC, et al. Altered functional properties of a TRPM2 variant in Guamanian ALS and PD. Proc Natl Acad Sci USA 2008; 105(46): 18029-34.

[201] Haraguchi K, Kawamoto A, Isami K, et al. TRPM2 contributes to inflammatory and neuropathic pain through the aggravation of pronociceptive inflammatory responses in mice. J Neurosci 2012; 32(11): 3931-41.

[202] Nazıroğlu M, Özgül C, Çelik Ö, Çiğ B, Sözbir E. Aminoethoxydiphenyl borate and flufenamic acid inhibit $\mathrm{Ca} 2+$ influx through TRPM2 channels in rat dorsal root ganglion neurons activated by ADP-ribose and rotenone. J Membr Biol 2011; 241(2): 69-75.
[203] Nazıroğlu M, Özgül C, Çiğ B, Doğan S, Uğuz AC. Glutathione modulates $\mathrm{Ca}(2+)$ influx and oxidative toxicity through TRPM2 channel in rat dorsal root ganglion neurons. J Membr Biol 2011; 242(3): 109-18.

[204] Klose C, Straub I, Riehle M, Ranta F, Krautwurst D, Ullrich S, Meyerhof W, Harteneck C. Fenamates as TRP channel blockers: mefenamic acid selectively blocks TRPM3. Br J Pharmacol 2011; 162(8): 1757-69.

[205] Ozgül C, Nazıroğlu M. TRPM2 channel protective properties of Nacetylcysteine on cytosolic glutathione depletion dependent oxidative stress and $\mathrm{Ca}(2+)$ influx in rat dorsal root ganglion. Physiol Behav 2012; 106(2): 122-8.

[206] Kraft R, Harteneck C. The mammalian melastatin-related transient receptor potential cation channels: an overview. Pflugers Arch 2005; 451(1): 204-11.

[207] Lee N, Chen J, Sun L, et al. Expression and characterization of human transient receptor potential melastatin 3 (hTRPM3). J Biol Chem 2003; 278(23): 20890-7.

[208] Grimm C, Kraft R, Sauerbruch S, Schultz G, Harteneck C. Molecular and functional characterization of the melastatin-related cation channel TRPM3. J Biol Chem 2003; 278: 21493-501

[209] Nealen ML, Gold MS, Thut PD, Caterina MJ. TRPM8 mRNA is expressed in a subset of cold-responsive trigeminal neurons from rat. J Neurophysiol 2003; 90: 515-20.

[210] Oberwinkler J, Philipp SE. Trpm3. Handb Exp Pharmacol 2007; $179 ; 253-67$.

[211] Oberwinkler J, Lis A, Giehl KM, Flockerzi V, Philipp SE. Alternative splicing switches the divalent cation selectivity of TRPM3 channels. J Biol Chem 2005; 280: 22540-8

[212] Wagner TF, Loch S, Lambert S, et al. Transient receptor potential M3 channels are ionotropic steroid receptors in pancreatic beta cells. Nat Cell Biol 2008; 10: 1421-30.

[213] Lechner SG, Frenzel H, Wang R, Lewin GR. Developmental waves of mechanosensitivity acquisition in sensory neuron subtypes during embryonic development. EMBO J 2009; 28: 1479-91.

[214] Staaf S, Franck MC, Marmige' re F, Mattsson JP, Ernfors P. Dynamic expression of the TRPM subgroup of ion channels in developing mouse sensory neurons. Gene Expr Patterns 2010; 10: 65-74.

[215] Grimm C, Kraft R, Schultz G, Harteneck C. Activation of the melastatin-related cation channel TRPM3 by D-erythrosphingosine. Mol Pharmacol 2005; 67: 798-805.

[216] Vriens J, Owsianik G, Hofmann T, et al. TRPM3 is a nociceptor channel involved in the detection of noxious heat. Neuron 2011; 70(3): 482-94.

[217] Ueda $\mathrm{H}$, Inoue $\mathrm{M}$, Yoshida $\mathrm{A}$, et al. Metabotropic neurosteroid/sigma-receptor involved in stimulation of nociceptor endings of mice. J Pharmacol Exp Ther 2001; 298; 703-10.

[218] Peier AM, Moqrich A, Hergarden AC, et al. A TRP channel that senses cold stimuli and menthol. Cell 2002; 108(5): 705-15.

[219] McKemy DD, Neuhausser WM, Julius D. Identification of a cold receptor reveals a general role for TRP channels in thermosensation. Nature 2002; 416(6876): 52-8.

[220] Tsavaler L, Shapero MH, Morkowski S, Laus R. Trp-p8, a novel prostate-specific gene, is up-regulated in prostate cancer and other malignancies and shares high homology with transient receptor potential calcium channel proteins. Cancer Res 2001; 61(9): 37609.

[221] Tsuzuki K, Xing H, Ling J, Gu JG. Menthol-induced Ca2+ release from presynaptic $\mathrm{Ca} 2+$ stores potentiates sensory synaptic transmission. J Neurosci 2004; 24(3): 762-71.

[222] Vanden Abeele F, Zholos A, Bidaux G, et al. Ca2+-independent phospholipase A2-dependent gating of TRPM8 by lysophospholipids. J Biol Chem 2006; 281(52): 40174-82.

[223] $\mathrm{Hu} \mathrm{HZ}$, Gu Q, Wang C, et al. 2-aminoethoxydiphenyl borate is a common activator of TRPV1, TRPV2, and TRPV3. J Biol Chem 2004; 279(34): 35741-8.

[224] Behrendt HJ, Germann T, Gillen C, Hatt H, Jostock R. Characterization of the mouse cold-menthol receptor TRPM8 and vanilloid receptor type-1 VR1 using a fluorometric imaging plate reader (FLIPR) assay. Br J Pharmacol 2004; 141(4): 737-45.

[225] Weil A, Moore SE, Waite NJ, Randall A, Gunthorpe MJ Conservation of functional and pharmacological properties in the distantly related temperature sensors TRVP1 and TRPM8. Mol Pharmacol 2005; 68(2): 518-27. 
[226] Macpherson LJ, Hwang SW, Miyamoto T, Dubin AE, Patapoutian A, Story GM. More than cool: promiscuous relationships of menthol and other sensory compounds. Mol Cell Neurosci 2006; 32(4): 335-43.

[227] Niforatos W, Zhang XF, Lake MR, et al. Activation of TRPA1 channels by the fatty acid amide hydrolase inhibitor 3'carbamoylbiphenyl-3-yl cyclohexylcarbamate (URB597). Mol Pharmacol 2007; 71(5): 1209-16.

[228] Colburn RW, Lubin ML, Stone DJ, Jr, et al. Attenuated cold sensitivity in TRPM8 null mice. Neuron 2007; 54(3): 379-86.

[229] Dhaka A, Murray AN, Mathur J, Earley TJ, Petrus MJ, Patapoutian A. TRPM8 is required for cold sensation in mice. Neuron 2007; 54(3): 371-8.

[230] Reid G, Flonta M. Cold transduction by inhibition of a background potassium conductance in rat primary sensory neurones. Neurosci Lett 2001; 297(3): 171-4.

[231] Viana F, de la Pena E, Belmonte C. Specificity of cold thermotransduction is determined by differential ionic channel expression. Nat Neurosci 2002; 5(3): 254-60.

[232] Munns C, AlQatari M, Koltzenburg M. Many cold sensitive peripheral neurons of the mouse do not express TRPM8 or TRPA1. Cell Calcium 2007; 41(4): 331-42.

[233] Zimmermann K, Leffler A, Babes A, et al. Sensory neuron sodium channel Nav1.8 is essential for pain at low temperatures. Nature 2007; 447(7146): 855-8

[234] Liu B, Qin F. Functional control of cold- and menthol-sensitive TRPM8 ion channels by phosphatidylinositol 4,5-bisphosphate. J Neurosci 2005; 25(7): 1674-81.

[235] Rohacs T, Lopes CM, Michailidis I, Logothetis DE. PI(4,5)P2 regulates the activation and desensitization of TRPM8 channels through the TRP domain. Nat Neurosci 2005; 8 (5): 626-34.

[236] Benedikt J, Teisinger J, Vyklicky L, Vlachova V. Ethanol inhibits cold-menthol receptor TRPM8 by modulating its interaction with membrane phosphatidylinositol 4,5-bisphosphate. J Neurochem 2007; 100(1): 211-24.

[237] Baron R. Neuropathic pain: a clinical perspective. Handb Exp Pharmacol 2009; 194: 3-30.

[238] Knowlton WM, McKemy DD. TRPM8: from cold to cancer, peppermint to pain. Curr Pharm Biotechnol 2011; 12(1): 68-77.

[239] Grimm C, Cuajungco MP, van Aken AF, et al. A helix-breaking mutation in TRPML3 leads to constitutive activity underlying deafness in the varitint-waddler mouse. Proc Natl Acad Sci USA 2007; 104: 19583-8.
[240] Xu H, Delling M, Li L, Dong X, Clapham DE. Activating mutation in a mucolipin transient receptor potential channel leads to melanocyte loss in varitint-waddler mice. Proc Natl Acad Sci USA 2007; 104: 18321-6.

[241] Kim HJ, Li Q, Tjon-Kon-Sang S, et al. A novel mode of TRPML3 regulation by extracytosolic $\mathrm{pH}$ absent in the varitint-waddler phenotype. EMBO J 2008; 27: 1197-205.

[242] van Aken AF, Atiba-Davies M, Marcotti W, et al. TRPML3 mutations cause impaired mechano-electrical transduction and depolarization by an inward-rectifier cation current in auditory hair cells of varitint-waddler mice. J Physiol 2008; 586: 5403-18.

[243] Zeevi DA, Frumkin A, Offen-Glasner V, Kogot-Levin A, Bach G. A potentially dynamic lysosomal role for the endogenous TRPML proteins. J Pathol 2009; 219: 153-62.

[244] Cable J, Steel KP. Combined cochleo-saccular and neuroepithelial abnormalities in the Varitint-waddler-J (VaJ) mouse. Hear Res 1998; 123: 125-36.

[245] Grimm C, Jörs S, Saldanha SA, et al. Small molecule activators of TRPML3. Chem Biol 2010; 17: 135-48.

[246] Wu LJ, Sweet T, Clapham DE. International Union of Basic and Clinical Pharmacology. LXXVI. Current progress in the mammalian TRP ion channel family. Pharmacol Rev 2010; 62: 381-404.

[247] Elg S, Marmigere F, Mattsson JP, Ernfors P. Cellular subtype distribution and developmental regulation of TRPC channel members in the mouse dorsal root ganglion. J Comp Neurol 2007; 503: $35-46$

[248] Alessandri-Haber N, Dina OA, Chen X, Levine JD. TRPC1 and TRPC6 channels cooperate with TRPV4 to mediate mechanical hyperalgesia and nociceptors sensitization. J Neurosci 2009; 29(19): 6217-28

[249] Ding J, Xiao Y, Lu D, DU YR, Cui XY, Chen J. Effects of SKF96365, a TRPC inhibitor, on melittin-induced inward current and intracellular $\mathrm{Ca} 2+$ rise in primary sensory cells. Neurosci Bull 2011; 27(3): 135-42.

[250] Ding J, Zhang JR, Wang Y, et al. Effects of a non-selective TRPC channel blocker, SKF-96365, on melittin-induced spontaneous persistent nociception and inflammatory pain hypersensitivity. Neurosci Bull 2012; 28(2): 173-81.

[251] Suzuki Y, Kodama D, Goto S, Togari A. Involvement of TRP channels in the signal transduction of bradykinin in human osteoblasts. Biochem Biophys Res Commun 2011; 410(2): 317-21. 